\section{Political Economy of Straw Houses: Traditional and Contemporary Way of Enhancing Sustainability of the Buildings}

\section{Egemen Sertyesilisik*}

Gozuyilmaz Engineering and Marine Industries Ltd., Izmir, Turkey

\section{Seyma Yilmaz}

Cevher Cam, Sumer Mah. Denizli, Turkey

\section{Begum Sertyesilisik}

Izmir Democracy University, Faculty of Architecture, Department of Architecture, Izmir, Turkey

*Corresponding author: egemens@alumni.bilkent.edu.tr

\section{$\Gamma$} crossef http://dx.doi.org/10.5755/j01.sace.28.1.27711

Cities, as production and consumption hubs, cause significant amount of global $\mathrm{CO}_{2}$ emissions and energy consumption. Climate change challenges world's welfare due to the global warming. Cities' environmental footprint can be reduced with the help of energy efficient and sustainable built environment which can further contribute to the wellbeing and welfare of the urban population contributing to the solution of the fuel poverty. Straw is a traditional and contemporary material having outstanding technical characteristics (e.g. thermal insulation). Straw is a traditional material as it has been used in sheltering starting from the ancient times. Straw is a contemporary material as it is used even in small buildings with the help of innovations. Furthermore, it is a cost effective material from initial investment as well as maintenance and repair aspects. Straw houses can reduce energy consumption. This can reduce countries' trade deficit due to the reduced demand for energy import, contributing to the solution of the fuel poverty. Straw is environmental friendly natural material. Constructing straw houses is important for sustainable living. Giving importance to the straw house construction can help reduction in the $\mathrm{CO}_{2}$ emission and in the energy consumption. Based on an in-depth literature review, this paper investigates political economy of straw houses and straw houses' contribution to the sustainability performance of the built environment. This paper introduces to the literature political economy of the straw houses and provides recommendations on how to widespread the use of straw houses.

Keywords: energy, environment, housing, politics, political economy of straw houses.

As none of the countries has unlimited financial power, efficient allocation of budget is important to generate welfare and to enable sustainable development. Climate change has started to challenge world's welfare. Effective fight against the climate change requires interdisciplinary action due to its consequences. Consequences of the climate change have started to become a threat for rights (Levy and Patz, 2015). Wallimann-Helmer (2019) has emphasized the importance of the justice in managing climate change. Especially, thanks to the Kyoto Protocol and Paris agreement many countries come together to reduce their $\mathrm{CO}_{2}$ emissions, and to reduce their environmental footprint. At this stage finding solution to unsustainable urbanization can support fight against climate change. Even if cities cover approximately $2 \%$ of the land surface of the world, they consume majority of energy and emit 75\% of $\mathrm{CO}_{2}$ (United Nations, 2014; Sertyesilisik \& Sertyesilisik, 2015:
JSACE $1 / 28$

Political Economy of Straw Houses: Traditional and Contemporary Way of Enhancing Sustainability of the Buildings

Received 2020/09/29

Accepted after revision 2020/12/22

\section{Introduction}

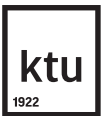

Journal of Sustainable Architecture and Civil Engineering Vol. 1 / No. 28 / 2021 pp. 15-25 DOI 10.5755/j01.sace.28.1.27711 
83). The building sector's consumption of $40 \%$ of main energy usage is a sample for Levermore (2008)'s statement who indicates that the built environment consumes big amount of energy and material (Levermore, 2008). European Union's targets for 2020, 2030 and 2050 regarding reduction in the greenhouse gas emissions and increase in the energy efficiency (European Union website, n.d.) emphasize need for and importance of improving sustainability performance of the built environment. Construction of environmental friendly houses like straw houses can reduce environmental harm caused by the construction industry $(\mathrm{Cl})$ and the built environment. Straw houses can contribute to the protection of the world's resources and for enhancing sustainability performance of the built environment. Furthermore, straw houses can contribute to the circular economy as they enable waste material to be used as an input.

Political economy of straw/straw houses is related with the political economy of sustainability and sustainable development. The three pillars of sustainability and political economy are interrelated. Sustainability is an important topic of the global political economy (The World Bank, 1982; Loshaj, 2016). Global environmental policies' topic can be covered by the global political economy which “... is the politics of international economic activities" (e.g. trade, international politics on economic integrations, etc.) (Goldstein \& Pevehouse, 2015: 371). Political economy is also concerned with the sustainable development as it is related with "... determining what political and/or economic factors ... are restricting the courses of action toward sustainable development" (Branco, 2008; Rogers \& Boyd, 2008; Loshaj, 2016: 5). Straw and straw houses can have potential to contribute to the establishment of the sustainable built environment and to the solution of the fuel poverty problem. Based on an in depth literature review, this paper investigates the political economy of straw houses and straw houses' contribution to the sustainability performance of the built environment.

Traditional and Contemporary Usage of Straw in the Built Environment
Although straw has been used in construction since the Paleolithic Age (Langlois, 2017), straw gained its popularity in late 1800s with the invention of baling machines (Steen, Steen, \& Bainbridge, 1994). Similarly, straw houses have been widespread in Nebreska due to the scarcity of other building materials (Amazon Nails, 2001) and they date back to 1800s as they are durable (Nunan, 2010). Contribution of the straw bale's usage as a construction material to the reduction in the housing costs has further resulted in widespread use of the straw houses (King, 2006; Offin, 2010). Straw houses are cost effective as straw is easy to find and construct (Magwood, 2014) Straw is a widely available material. For example, in North America, the amount of straw produced annually is enough for residential building construction (Garas, Allam, \& El Dessuky, 2009). Apart from residential architecture, many churches, schools, and community and youth centers have been constructed by people who will take advantage of the building to be built (Magwood, et al., 2005). Thanks to the different-sized modular units, the usage of straw bales could reduce buildings' construction time period, and the construction waste (Walker, Thomson \& Maskell, 2016). Furthermore, its construction technique is basic and it enables design flexibility (King, 2006). Research in the field of different usage of straw further contributes to its widespread [e.g., the 'ModCell ${ }^{\circledR}$ ' (Balehaus at bath n.d.; Guarneri, 2014: 732; ModCell, n.d.].

Nowadays, there are ongoing attempts to construct eco-friendly buildings with biodegradable and renewable building materials because of the depletion of the sources and deteriorated world habitat. Kołakowski (2005) stated that straw, which is a raw, traditional and grown naturally material, is one of these building materials (Jagielak, 2015: 1). Amazon Nails (2011) indicates that approximately 1000 new structures per year are built in the world. Furthermore, Prof. Rueger prepared a map in 2010 which shows that there are approximately 700 straw bale dwellings in France, 150 in Germany, and 104 in Austria (Atkinson, 2010). Straw is used both in traditional and contemporary ways.

Traditional Usage of Straw: Traditional construction with straw bales can be pointed off under 3 main types: load-bearing systems as in Nebraskan style, non-load-bearing systems, and hybrid systems 
(Magwood, Mack, \& Therrien, 2005). Load bearing system is the original one which was firstly used by the Nebraskan settlers in the USA (Jones \& Breese, 2009). The bales are pinned to foundation and to each other to be able to carry the wooden roof structure (Magwood, 2014). Walker, et al., (2016) indicated that the original usage way of the straw bale is still an effective way for low-rise buildings. Moreover, if straws are baled, massed, elaborated, and plastered with any earthen renders, they could bear residential scaled loads (Bendapudi, Potnuru, Varanasi \& Saha, 2012). One of the most important advantages is simplicity of its execution. This method is the easiest way for building load bearing structure as the non-professionals can build their small scale building with the help of basic guides (Myhrman \& MacDonald, 1997). Another advantage of this method is less usage of wood or steel in the construction (Wilson, 1995). The second method is the non-loadbearing system where wood, steel or concrete frameworks carry the roof whereas the bales act as an infill material (Jagielak, 2015). In other words, load-bearing mission is transferred to column and beams, thereby, bales turn into just an infill material for the structure. In this method, it is possible to prevent the straw bales from being affected by adverse weather conditions by starting construction from the structural system and roof (Walker, et al., 2016). Even if the high insulation properties of straw are utilized in this method, this method is less sustainable compared to the first one due to the need for large amount of timber/steel (Amazon Nails, 2011). In the third method which is the hybrid method, the most suitable features of the previous two methods are used as straw bales act as a bearer with the main structure, and at the same time provide design flexibility (Magwood, et al., 2005). Apart from these methods, bales can be used as flooring and ceiling material with their high insulation properties (Atkinson, 2010).

Contemporary Usage of Straw: Nowadays, different methods are being researched to use the straw bale more efficiently and to spread the usage area. Prefabricated panel systems could be shown as an example of these researches. Researchers at the University of Bath's Building Research Establishment (BRE) Centre for Innovative Construction Materials had developed new ways of using straw bales for construction which is 'ModCell ${ }^{\circledR}$ '(Balehaus at Bath, n.d.). In this system, which is developed based on the prefabrication method, the straw in the timber frames makes use of the fast and flexible design of modularity (ModCell, n.d.). It is seen that straw has expanded its usage area in contemporary architecture with this prefabrication method, which can be used in the construction of many structures which all have different scales and flow schemes such as school buildings (e.g., Glenfrome Primary School, Waterfoot Primary School), student centers (e.g., Harlow Learning Center), media centers (e.g., Knowle West Media Centre), residences (e.g., Shirehampton Eco-Homes Bristol), co-houses (e.g., LILAC Affordable Co-houses, BaleHaus at Bath), cafes (e.g., Holme Lacy Campus Cafe), and visitor centers (e.g., Hengistbury Head Visitor Centre) (ModCell, n.d.). Another example of the new way of the straw bale usage is the panel-cladding used in the Résidence Jules Ferry building with an eight-story in St-Dié-des-Vosges in France (Walker, et al., 2016). Considering that the traditional way of the straw bale is mostly used in small-scale buildings, it can be said that with the advancing technology in contemporary architecture, the range of building types and the building scale which are constructed by using straw have been expanded. Magwood et al. (2005) stated that commercial buildings could be more suitable for construction with straw bale than residential buildings because they are prefabricated and modular. Furthermore, straw houses and straw can support sustainable contemporary life. After excessive natural disasters, scarcities, and global warming issues, people are seeking a new way of life that is healthy, sustainable, and harmless to the nature. Straw Bale construction is one of the original techniques for creating that kind of living area (Guarneri, 2014). StrawBale Village proposal by One Community can be given as an example of this new way of sustainable contemporary life (One Community, 2020). One Community -which proposes mini-village models with different eco-building methods- benefits in their second proposed village from the modular and expandable nature of the straw bales for creating a sustainable, accessible, and collective way of living (One Community, 2020). 


\section{Straw and Sustainability}

Straw houses have various benefits. They perform well especially with regard to: sustainability, energy efficiency, embodied energy, water efficiency, embodied water, and embodied carbon. $\mathrm{Cl}$ is a carbon-emission intensive industry. Furthermore, many of the construction products have high amount of embodied carbon. Today, in many countries, there is an increasing tendency to reduce the negative impacts of the $\mathrm{Cl}$ on the environment with the help of sustainable and green construction. Straw bale usage in the construction can reduce the greenhouse gas emissions significantly reducing carbon footprint and embodied carbon of the building (Jones \& Breese, 2009). Straw is one of the natural building materials which has many different advantageous features in terms of sustainable construction. Contrary to the intensive energy consumption, carbon emission and water consumption in the modern building material production process, straw is more environment-friendly (Walker, et al., 2016). Straw which is a waste material, is a natural and renewable material which reduces the environmental footprint of the building throughout its lifecycle (Bendapudi, et al., 2012). Furthermore, usage of straw as a building material, instead of burning it, can contribute to the waste recycling in a sustainable way (Nunan, 2010). The usage of locally available straw can further reduce embodied carbon, carbon emissions, energy and transportation cost, as well as support the local economy. Furthermore, considering the demolition processes of buildings, straw does not cause environmental pollution as it is dissolved in nature easier.

Energy Efficiency and Embodied Energy: $\mathrm{Cl}$ is energy intensive. More than 30\% of the worldwide energy consumption results from the $\mathrm{Cl}$ (Andrić, et al., 2017). Straw has low embodied energy. The choice of straw bale wall with 6:1:1 section of plaster can be a better selection than traditional construction style of wooden frame with brick siding thanks to its six times lower embodied energy (Offin, 2010). Embodied energy value of the straw bale has various values depending on analysis type with different parameter [e.g. 0,24 MJ/kg (North, n.d.; Offin, 2010: 35), 0,4 MJ/kg (Edminster \& Alcorn, 1995; Offin, 2010: 35), 0,0014 MJ/kg (BRE, 2001; Offin, 2010: 35)]. As Cl is carbon emission intensive, improvement of the energy efficiency is important and it can be supported by the usage of straw-bale due to its high thermal insulation value (Amazon Nails, 2001). This can enhance reduction in the heating and cooling loads. Reduction in the rural populations' dependence on the coal can contribute to the sustainable development (Bendapudi, et al., 2012). This reduction can take place with the usage of straw as a main building material as it is a local and waste product of harvested grain. Houses constructed with straw generally do not require any additional wall insulation as R-value for straw bale walls ranges between R-17 and R-65 (Stone, 2003; Offin, 2010). For this reason, considering increase in the world population and global warming, the straw bale structure can be adopted as a housing solution which can contribute to the reduction in the usage of fossil fuels (Kennedy, Smith \& Wanek, 2015).

Embodied Water: Buildings consume important amount of energy and water (during construction, material manufacturing phase) in the production/manufacturing phase as well as in the occupation and maintenance phase. Water usage is a significant environmental problem especially in hot and dry climates. All products need water to be produced. As the total water used in whole stages of the production chain means virtual water, the more the material is processed, the more virtual water is consumed. As straw bales do not undergo industrial processing, the virtual water value is less than many other modern construction materials (e.g., steel, concrete). The considerable amount of water usage for straw bale occurs during the growing process of grains.

Initial investment, operation and maintenance costs: Straw houses have relatively low initial investment, operation and maintenance costs. This potential advantage of the straw houses can contribute to the environmental, social and economic sustainability as well as to the affordability of housing (Table 1). Straw houses can be considered as a solution to the affordable housing scarcity problem. Straw houses are cost effective enabling cost savings throughout the building life cycle periods especially in the construction and maintenance period as they can enable reduction in the labor cost due to the easy/simple construction process and as they can enable 
reduction in the heating and ventilation due to their high heat insulation (Garas et al., 2009). Simplistic building method of straw can enable unexperienced people to participate in the design and construction processes (Jones \& Breese 2009). The cost of a straw bale building varies by: region, climate, codes and permit requirements; the method of construction as well as the size and design of the building (Woolley \& Kimmins, 2000); the price paid per bale and distance of the place from where the straw is purchased (Steen et al., 1994). Furthermore, straw houses' operation period is cost effective due to the energy efficiency and reduced energy cost. For example, in Mongolia, straw bale buildings have approximately $80 \%$ less energy consumption compared to the conventional buildings (Bainbridge, 2004; Garas et al., 2009). The heating costs of straw houses can be reduced by $75 \%$ annually compared to traditional residential buildings (Jones \& Breese, 2009:14). Straw can balance the air conditions inside of the houses which can give an opportunity to reduce maintaining cost of the building (Steen et al., 1994). According to a study of the Canada Mortgage and Housing Corporation, the usage of heating energy for space in the straw bale houses is at least 20\% lower than the modeled traditional houses (Technical Series 02-115. 2002; Garas et al., 2009). Life of straw houses can last for hundred years with very low maintenance costs (Steen et al., 1994: 38-39).

Its long life duration and low maintenance costs (Steen et al., 1994)

Its contribution to the reduction in the usage of fossil fuels (Kennedy, Smith \& Wanek, 2015)

High thermal insulation value (Amazon Nails, 2001; Stone, 2003; Offin, 2010; Garas et al., 2009)

Low embodied energy (Offin, 2010)

Reduced energy demand (Bainbridge, 2004; Garas et al., 2009) and reduced heating costs (Jones \& Breese, 2009; Technical Series 02-115. 2002; Garas et al., 2009)

Low embodied carbon (Jones \& Breese, 2009)

Its contribution to waste recycling (Nunan, 2010)

Easy and fast construction (Jones \& Breese 2009; Nunan, 2010)

Moisture and fire related concerns are among the main concerns which need to be addressed throughout the entire lifecycle of the straw houses starting from the design phase so that sustainability and affordability of houses can be achieved (Magwood, et al., 2005). As the moisture content over the acceptable ratios can cause serious health problems as it can cause moisture and reproduction of mold spores, straw bale designers and researchers need to give a special attention to this issue (King, 1998). The effective solutions to deal with problems related with water and vapor depend on the climate and region of the building (Carfrae, 2011). For example, Marc Rosenbaum suggests that in cold climates, vapor-retardant paint should be used on the interior wall, whereas in hot and humid climates, this paint should be used on the exterior (Wilson, 1995). Another precaution to prevent moisture is placement of the air barrier between the bottom of the bales and the footing as the bales can be recommended to be raised approximately $20 \mathrm{~cm}$ above ground level (Steen et al., 1994). Furthermore, detailing of windows is essential measure to prevent from moisture leakage (Kennedy et al., 2015). Despite of the concerns for the moisture, Steen et al. (1994) state that there are straw bale buildings which don't have any problem of deterioration of the bales in Washington which receive 75 inches of rain per year from 1970s and 1980s (Steen et al., 1994). Fire resistance is another important aspect of straw houses. Plastered straw bale walls have lower fire risk than traditional timber frame walls (Steen et al., 1994). In accordance with the statements of the Canada Mortgage and Housing Corporation, it has been proved that straw bales have high fire resistance (Steen et al., 1994). Fire retardants (e.g. aluminum sulfate) can be applied to the bale to reduce fire
Table 1

Examples of main characteristics of straw houses which can contribute to the sustainability and affordability of houses 
risk of the building (Myhrman \& MacDonald, 1997). The greatest risk of fire, however, can emerge due to loose straw that can agglomerate on the worksite. As especially in windy conditions, the flames can easily spread through these straws, sweeping loose straw and storing away from building is an important issue (Myhrman \& MacDonald, 1997).

Political Economy of Straw Houses
Political economy of straw houses is related with the straw's performance and effects regarding to the three pillars of sustainability (Fig. 1). Straw houses can have impacts and contributions to these three pillars of sustainability which can act as drivers for increasing demand for them (Fig. 1).

Straw and straw houses can have impact on the environmental sustainability with the help of their low environmental footprint due to their energy efficiency, water efficiency, low embodied energy, carbon and water as well as their contribution to the circular economy. Straw can substitute some of the materials having higher embodied energy, carbon, and water as well as reduce their market share. According to Peñaloza et al. (2018: 1025), there is a necessity to urgent mitigation measures for Cl's GHG emissions as it causes "19\% of the global GHG emissions." (Peñaloza et al., 2018: 1025). As building straw houses can help to protect the environment, they can help governments and NGOs to reduce their spending to protect the environment. Protecting environment and reducing air pollution can make people healthier reducing their health care spending.

Straw and straw houses can contribute to the social sustainability due to relatively fast and easy construction process, relatively low construction/initial investment cost, operation and maintenance costs heating and cooling costs (due to relatively low active heating and ventilation requirements). Easy construction process can enable creation of job opportunities for relevant workforce or they can enable the potential home owners to build their own houses. Fast construction process can enable demand for housing to be fulfilled fast even in the post-emergency or post-disaster phases. Using straw is relatively faster option for the construction in terms of both preparation and execution process (e.g. no curing or drying period for the straw; no fabrication process for the straw) (Nunan, 2010). Easy and fast construction process of straw houses as well as their relatively low initial investment, operation and maintenance cost can enable straw houses to act as affordable housing and post-disaster housing. These potential benefits of straw houses can support welfare and wellbeing of the occupants.

Straw and straw houses can have impact on the economic sustainability and welfare creation. Enhanced circular economy can reduce the demand for and consumption of the raw materials which can be used in other value added production processes and products. Furthermore, potential contributions of the straw houses in reducing environmental footprint of the $\mathrm{Cl}$ can contribute to the wellbeing of the occupants and to reduce health care spending. Potential contribution of the straw and straw houses to the reduction in the energy demand (Bainbridge, 2004; Garas et al., 2009) for construction and operation of the built environment can strengthen countries' economy through reduced energy deficiency. As $\mathrm{Cl}$ is responsible for at least $30 \%$ of the global energy consumption (Andrić et al., 2017), energy efficiency is important to reduce energy trade gap and to enhance sustainable development (Berk \& Cin, 2018). Even in developed countries energy trade deficiency plays an important role in the economy. For example, energy caused America's trade gaps (Tsafos, 2018). Governments can invest more owing to this kind of energy saving which will enhance welfare of the people. They can allocate their budget more on investment to respond to their societies' needs. Furthermore, people who have reduced their energy spending, can spend more on leisure and on other investments which can make economy vivid and lead to the economic development. These examples reveal that straw houses are among the other factors which can influence the sustainable development.

Environmental, social, economic, political, legal, technical and innovation aspects can act as constructs of the political economy of straw houses (Fig.1). They can act as enablers for wide spread- 
ing straw material usage and straw houses' constructions. These constructs influence each other. Among these constructs, political and economic factors can act as key enablers and drivers for straw and straw houses (Fig. 1). For example, Townsend et al. (2018)'s research on the availability of wheat straw for bioenergy generation in England, revealed the importance of pricing policy and its impact on the motivation of farmers for exploring innovative ways for increasing straw supply. Furthermore, policies and economic decisions encouraging research and development activities on innovative ways of using straw can further contribute to the wide spreading of straw material and straw houses. There are various examples for research and developments which can contribute to the innovations having potential to contribute to the widespread usage of straw [e.g. enhancing durability of straw focusing on straw types' water sorption in wall construction (Yin, et al., 2018); usage of different straw types (lavender and barley) as bio aggregates in earth bricks (Giroudon et al., 2019); enhancing efficiency in the straw resources' usage (straw return versus usage of straw briquette fuel as a substitute for rural heating coal) (Zhang et al., 2019); investigation of straw's usage in methane production (Guo et al., 2019); optimum straw return-to-field ratio (Liu et al., 2019); hygrothermal and funistatic properties of two new straw blocks on the northern wall of a solar greenhouse (Ren et al., 2019), etc.].

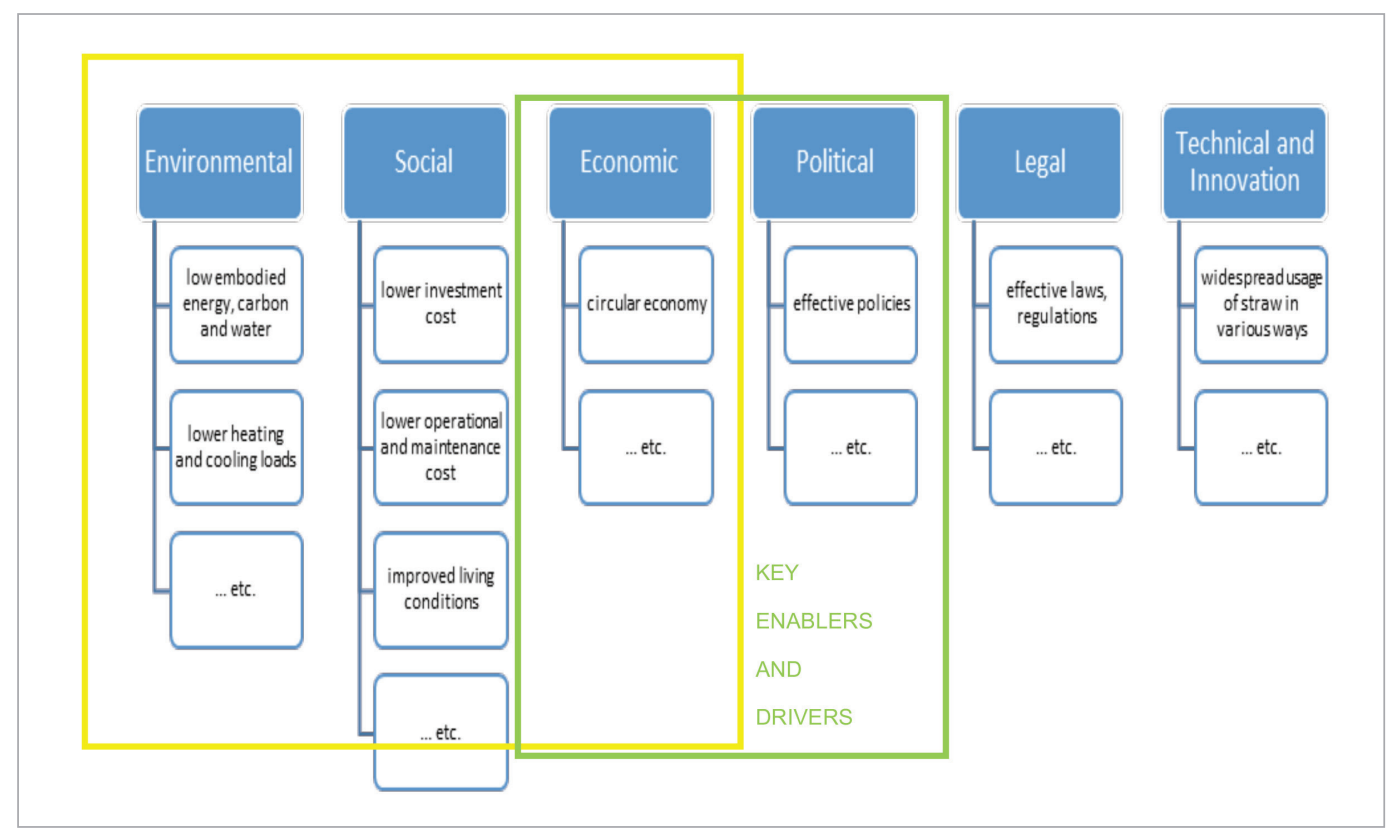

Effective policies, laws, and regulations need to be in integrity and in compliance with the global climate justice and urban climate justice. Bulkeley et al. (2013) have emphasized the relationship between climate change politics and justice. Furthermore, Michalec et al. (2019) introduced smart and just city concept (Michalec et al., 2019). Based on the UNDP (2016)'s definition of human development, Alves \& Mariano (2018) have emphasized relationship between climate justice and human development. Urban climate justice can influence emergence of new laws which can contribute to the sustainable development and encourage construction of environmental friendly buildings and cities. How to implement these new laws is also part of the political economy. "...the political economy endeavors to connect political and economic procedures within a nation." (The World Bank, 1982; Loshaj, 2016: 4). Examples for such procedures can include water reforms or ways for implementation of new laws (The World Bank, 1982; Loshaj, 2016). Effectiveness of policies, laws, and regulations is related with their economic impacts which can influence supply of and demand for straw based materials and straw houses. Governments can encourage businessmen to build
Fig. 1

Political economy aspects of the straw houses 
straw houses. Governments can reduce taxes or give subsidies to the businessmen who want to build straw houses or who want to invest in innovations related with straw materials. Furthermore, effectiveness of the policies, laws and regulations depends on the stakeholders' contribution as well as on the systematic approach. Main stakeholders and their main roles in enhancing political economy of the straw and straw houses have been illustrated in the Fig. 2. Climate change policies (both mitigation and adaptation policies) can be managed in an integrated way with the help of effective urban governance and with the participation of local governments (Lee \& Painter, 2015). Furthermore, political feasibility depends on societal transformation and social justice (Patterson et al., 2018). Effectiveness of the climate policies and their acceptance can be further enhanced in case policy makers consider long-term effects of climate policy (Bretschger, 2017). Furthermore, academics and researches can collaborate further to enhance effectiveness and widespread usage of straw in the $\mathrm{Cl}$ through their research and development activities. Research funds can encourage their research activities in this field. These funds together with effectively allocated subsidies to the manufacturers can foster widespread usage of this traditional material as a contemporary material in contemporary built environments. Architecture and civil engineering undergraduate education curriculums can be effective tools to enhance future construction professionals' knowledge on and preference of straw materials usage in an innovative and contemporary way.

Fig. 2

Main stakeholders and their main roles in enhancing political economy of the straw and straw houses

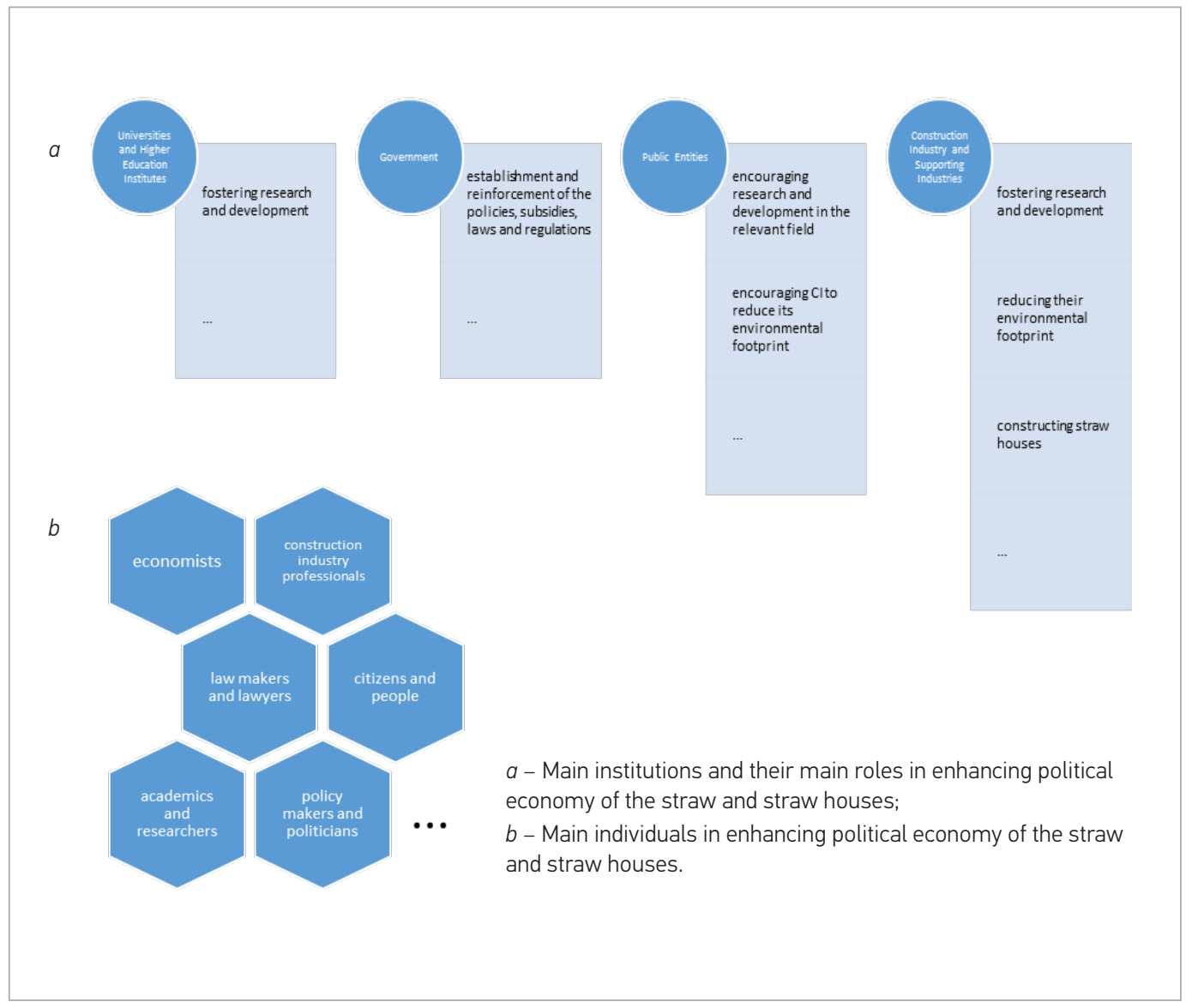

Political economy of straw houses needs to be considered as inputs to the housing policies. Sustainability and affordability performance of straw houses highlight their important role in housing policies and sustainable development policies. 
Humanity's environmental footprint has been asymptotically increased since the first industrial revolution. Humans should use the world's natural resources more efficiently, as failure to do so can obstacle sustainable living on earth. Straw, as a traditional and contemporary material, can provide sustainable solutions. Straw and straw houses can contribute to dealing with this challenge as they can support and protect nature and natural resources with the help of their low embodied energy, carbon and water. Their potential contribution to the three pillars of sustainability and to the sustainable development make them a subject of the political economy. This paper focused on the political economy of straw houses and straw houses' contribution to the sustainability performance of the built environment. Political economy aspects of straw houses were explained under the environmental, social, economic, political, legal, technical and innovation categories which are interrelated. These categories are the main pillars of the political economy of straw houses and their effectiveness and success depends on the successful management of their relationship and their impact to each other as well as on the effective contributions of all stakeholders. Further studies can focus on how to widespread straw material usage in developing and underdeveloped countries to fulfill their sustainable development needs.

Alves, M.W.F.M., Mariano, E.B. Climate justice and human development: A systematic literature review. Journal of Cleaner Production, 2018; 202: 360-375. https://doi.org/10.1016/j.jclepro.2018.08.091

Amazon Nails. Information guide to straw bale building, for self-builders and the construction industry. Amazon Nails, Hollinroyd Farm, Todmorden, OL14 8RJ., (19, 26); 2001.

Andrić, I., Pina, A., Ferrão, P., Fournier, J., Lacarrière, B., Le Corre, 0 . The impact of climate change on building heat demand in different climate types. Energy and Buildings, 2017; 149: 225-234. https://doi.org/10.1016/j. enbuild.2017.05.047

Atkinson, C. Why build with straw? A Nuffield Farming Scholarships Report by Carol Atkinson. 2010

Balehaus at Bath (n.d.). "About the project", Retrieved January 23, 2018, from http://www.bath.ac.uk/ace/ research/cicm/low-carbon-materials/balehaus/about/

Bendapudi, S.C.K., Potnuru A., Varanasi K., Saha P. Straw Bale as Sustainable Material. International Journal of Earth Sciences and Engineering, 2012; 05: 628-634.

Berk, C., Cin, K.O. On Energy Dependence, Current Account Deficit and Population in Turkey. Open Journal of Business and Management, 2018; 6, 183-192. https://doi.org/10.4236/ojbm.2018.61012

Branco, M. C. The Political Economy of the Human Right to Water. Publisher: Universidade de Évora, Portugal; 2008.

Bretschger, L. Climate policy and economic growth. Resource and energy economics, 2017; 49, 1-15. https:// doi.org/10.1016/j.reseneeco.2017.03.002

Bulkeley, H., Carmin, J., Broto, V.C., Edwards, G.A.S. Climate justice and global cities: Mapping the emerging discourses. Global Environmental Change, 2013; 23: 914925. https://doi.org/10.1016/j.gloenvcha.2013.05.010

Carfrae, J. The moisture performance of straw bale construction in a temperate maritime climate (Unpublished $\mathrm{PhD}$ thesis). University of Plymouth; 2011. Retrieved from http://strawbalebuildinguk.com/wp-content/ uploads/2017/09/Jim_Carfrae_Thesis.pdf

Edminster, \& Alcorn, V. Investigation of environmental impacts: straw bale construction. Pacifica, CA: Design Avenues. 1995. Retrieved from http://buildwellsource. org/materials3/materials-natural-rural/straw-1/ straw-bale/9-investigation-of-environmental-impacts-strawbale-construction-ann-v-edminster-1995/file

European Union website n.d. EU Climate Action https:// ec.europa.eu/clima/citizens/eu_en

Garas, G., Allam, M., El Dessuky, R. Straw bale construction as an economic environmental building alternative-a case study. ARPN Journal of Engineering and Applied Sciences, 2009; 4(9), 54-59.

Giroudon, M., Laborel-Preneron, A., Aubert, J.E., Magniont, C. Comparison of barley and lavender straw as bioaggregates in earth bricks. Construction and Building Materials, 2019; 202, 254-265. https://doi. org/10.1016/j.conbuildmat.2018.12.126

Goldstein, J. S. \& Pevehouse, J. C. “Uluslararası Ilişkiler", Tarcan Matbası; 2015.

Guarneri, B. A. Architect Werner Schmidt's Straw-Bale Construction. In Key Engineering Materials, Vol. 600, pp. 727-738. Trans Tech Publications; 2014. https://doi. org/10.4028/www.scientific.net/KEM.600.727

Guo, H., Cheng, Y., Huang, Z., Urynowicz, M.A., Liang, W., Han, Z., Liu. Factors affecting co-degradation of coal and
Conclusions

\section{References}


straw to enhance biogenic coalbed methane. Fuel, 2019; 244, 240-246. https://doi.org/10.1016/j.fuel.2019.02.011

Jones, B., \& Breese, J. Building with straw bales : a practical guide for the UK and Ireland. Totnes, Devon : Green Books; 2009. Retrieved from http://0-search.ebscohost. com.divit.library.itu.edu.tr/login.aspx?direct=true\&db=cat01696a\&AN=itu.b2665742\&lang=tr\&site=eds-live Kennedy, J. F., Smith, M. G., Wanek, C. The Art of Natural Building: Design, Construction, Resources" (Vol. Second editon, completely revised expanded \& updated). Gabriola Island, BC Canada: New Society Publishers; 2015. Retrieved from http://0-search. ebscohost.com.divit.library.itu.edu.tr/login.aspx?direct=true $\& d b=n l e b k \& A N=983294 \&$ lang=tr $\&$ site=eds-live King, B. Design of straw bale buildings: the state of the art. San Rafeal, CA: Green Building; 2006. Retrieved from http://www.ecobuildnetwork.org/projects/design-of-straw-bale-buildings-book

King, B. Straw Bale Construction. Building Standards, (18-24); 1998. Retrieved from http://www.greenhomebuilding.com/pdf/buildingstandards_strawbale.pdf Langlois, J. Straw Bale Construction: A Sustainable and Renewable Building Material; 2017. Retrieved January 22, 2018 from https://buildabroad.org/2017/02/07/ straw-bale-construction/

Lee, T., Painter, M. Comprehensive local climate policy: The role of urban governance. Urban Climate, 2015;14, 566-577. https://doi.org/10.1016/j.uclim.2015.09.003

Levermore, G. A review of the IPCC Assessment Report Four, Part 1: the IPCC process and greenhouse gas emission trends from buildings worldwide. Building Services Engineering Research and Technology, 2008; 29:349-61. https://doi.org/10.1177/0143624408096263

Levy, B.S., Patz, J.A. Climate Change, Human Rights, and Social Justice. Annals of Global Health, 2015; 81(3): 310-322. https://doi.org/10.1016/j.aogh.2015.08.008

Liu, B., Wu, Q., Wang, F., Zhang, B. Is straw return-tofield always beneficial? Evidence from an integrated cost-benefit analysis. Energy, 2019; 171: 393-402. https://doi.org/10.1016/j.energy.2019.01.031

Loshaj, D. The Political Economy of the Right to Water - Case Study Albania. Linnaeus University - Växjö, Sweden Department of Political Science 1SK176, Thesis in Sustainable Development Law, Autumn 2016. http://www.diva-portal.org/smash/get/diva2:1059674/ FULLTEXT01.pdf

Jagielak, M., Strawbale Building in Poland, Cracow University of Technology, Wydział Architektury, ul.Warszawska 24, 31-155 Kraków, Poland, 2015. Retrieved January 16, 2018 from https://www.scribd.com/document/238251026/ Strawbale-building-in-Poland-Maciej-Jagielak-0-pdf Magwood, C. (2014). Making better buildings: a comparative guide to sustainable construction for homeown- ers and contractors. Canada: New Society Publishers. Retrieved from https://0-ebookcentral-proquest-com. divit.library.itu.edu.tr

Magwood, C., Mack, P., \& Therrien, T. More Straw Bale Building: A Complete Guide to Designing and Building with Straw. Gabriola Island, B.C., Canada: New Society, 2005.

Michalec, A.O., Hayes, E., Longhurst, J. Building smart cities, the just way. A critical review of "smart" and "just" initiatives in Bristol, UK. Sustainable Cities and Society, 2019; 47: 101510. https://doi.org/10.1016/j.scs.2019.101510

Myhrman, M. A., MacDonald, S. O. Build it with bales: a step-by-step guide to straw-bale construction, Tuscon, AZ: Out On Bale; 1997. Retrieved January 15, 2018, from http://www.dcat.net/about_dcat/images/BIWB/ BIWB\%20v2\%20ALL\%20PAGES.pdf

ModCell n.d. Sustainable pre-fab Straw Bale Panel Construction. Retrieved January 24, 2018, from http:// www.modcell.com/

Nunan, J. Complete Guide to Alternative Home Building Materials \& Methods Including Sod, Compressed Earth, Plaster, Straw, Beer Cans, Bottles, Cordwood, and Many Other Low Cost Materials. Atlantic Publishing Group, Ocala, Florida; 2010.

Offin, M. Straw bale construction: assessing and minimizing embodied energy. Masters Dissertation, Environmental Studies, Queen's University, Kingston, Ontario, Canada; 2010.

One Community (March 29, 2020). “Straw Bale Village - One Community Pod 2". Retrieved November 25, 2020, from https://www.onecommunityglobal.org/ straw-bale-village/

Patterson, J.J., Thaler, T., Hoffmann, M., Hughes, S., Oels, A., Chu, E., Mert, A., Huitema, D., Burch, S. \& Jordan, A. Political feasibility of $1.5 \mathrm{C}$ societal transformations: the role of social justice. Current Opinion in Environmental Sustainability, 2018; 31: 1-9. https:// doi.org/10.1016/j.cosust.2017.11.002

Ren, J., Zhao, Z., Zhang, J., Wang, J., Guo, S., Sun, J. Study on the hygrothermal properties of a Chinese solar greenhouse with a straw block north wall. Energy \& Buildings, 2019; 193, 127-138. https://doi. org/10.1016/j.enbuild.2019.03.040

Rogers, P., Boyd, J. A. An Introduction to Sustainable Development. Publisher: Routledge; 2008.

Peñaloza, D., Erlandsson, M., Berlin, J., Wålinder, M., Falk, A. Future scenarios for climate mitigation of new construction in Sweden: Effects of different technological pathways. Journal of Cleaner Production, 2018; 187: 1025-1035. https://doi.org/10.1016/j.jclepro.2018.03.285

Sertyesilisik, B., Sertyesilisik, E. Sustainability leaders for sustainable cities, In: Leadership and Sustainability in the Built Environment. Routhledge Taylor \& Francis Group New York; 2015. 
Steen, A. S., Steen, B., Bainbridge, D. A. The straw bale house. White River Junction, Vermont: Chelsea Green Publishing; 1994.

Stone, N. Thermal Performance of Straw Bale Wall Systems, Ecological Building Network (EBNet); 2003. Retrieved from http://www.ecobuildnetwork.org/pdfs/ Thermal_properties.pdf

Technical Series 02-115. Energy Use in Straw Bale Houses. Canada Mortgage and Housing Corporation; 2002. http://buildingsgroup.nrcan.gc.ca

The World Bank. World Development Report 1982: Agriculture and Economic Development. New York: Oxford University Press; 1982.

Townsend, T.J., Sparkes, D.L., Ramsden, S.J., Glithero, N.J., Wilso P. Wheat straw availability for bioenergy in England. Energy Policy, 2018; 122: 349-357. https:// doi.org/10.1016/j.enpol.2018.07.053

Tsafos, N. Can Energy Close America's Trade Deficit?, the Center for Strategic and International Studies, July 10, 2018 http://www.csis.org/analysis/can-energy-close-americas-trade-deficit

UN. The future we want: Sustainable cities; 2014. http:// www.un.org/en/sustainablefuture/cities.shtml\#facts Walker, P., Thomson, A., \& Maskell, D. Straw Bale Construction. In Nonconventional and Vernacular Con- struction Materials. Cambridge, USA: Elsevier Science \& Technology, 2016: 127-155. https://doi.org/10.1016/ C2014-0-00842-8

Wallimann-Helmer, I. Justice in managing global climate change. In: Letcher, T. (Ed.) Managing global warming: an interface of technology and human issues. London Cambridge, Academic Press, 751-768; 2019. https:// doi.org/10.1016/B978-0-12-814104-5.00026-0

Wilson, A. Straw: the next great building material? Environmental Building News 4, no.3 (May-June): 1, 11-16; 1995. Retrieved January 23, 2018, from https://www.buildinggreen.com/feature/straw-next-great-building-material Woolley, T. M., \& Kimmins, S. “Green Building Handbook: Volume 2: A guide to building products and their impact on the environment" (Vol. 2). London. E \& FN SPON: Taylor \& Francis Group, 2000

Yin, X., Lawrence, M., Maskell, D., Ansell, M. Comparative micro-structure and sorption isotherms of rice straw and wheat straw. Energy \& Buildings, 2018; 173: 11-18. https://doi.org/10.1016/j.enbuild.2018.04.033

Zhang, S., Deng, M., Shan, M., Zhou, C., Liu, W., Xu, X., Yang, $X$. Energy and environmental impact assessment of straw return and substitution of straw briquettes for heating coal in rural China. Energy Policy, 2019; 128 : 654-664. https://doi.org/10.1016/j.enpol.2019.01.038

\section{EGEMEN \\ SERTYESILISIK}

Position at the organization

Freelance consultant in Gozuyilmaz Engineering and Marine Industries Ltd.

\section{Main research area}

Sustainability, sustainability policies, political economy

\section{Address}

Gozuyilmaz Engineering and Marine Industries Ltd., Izmir, Turkey E-mail: egemens@alumni.bilkent.edu.tr

\section{ŞEYMA \\ YILMAZ}

Position at the organization

MSc Architect in Cevher Cam

\section{Main research area}

Sustainability, construction project management

\section{Address}

Cevher Cam, Sumer Mah.

Denizli, Turkey

E-mail:

seyma.ylmaz.93@gmail.com

\section{BEGUM SERTYESILISIK}

Position at the organization

Professor, Izmir Democracy University, Faculty of Architecture, Department of Architecture

\section{Main research area}

Sustainability, construction project management

\author{
Izmir Democracy University, \\ Faculty of Architecture, \\ Department of Architecture, \\ Izmir, Turkey \\ E-mail: \\ begum_sertyesilisik@hotmail.com
}

\section{About the Author}

